\title{
Dissecting Disaster Responses during COVID-19: An eThekwini Municipality Experience
}

\author{
Evangelos A. Mantzaris \\ ORCiD ID: https://orcid.org/0000-0003-0490-6953
}

\section{Bethuel Sibongiseni Ngcamu ORCiD ID: https://orcid.org./0000-0002-1507-7583}

\section{Abstract}

The national Institute for Communicable Diseases confirmed a first COVID19 patient on the 05 March 2020, which influenced the South African government (10 days later) to declare a National Disaster, as per Section 27(2) of the Disaster Management Act of 2002. This study is triggered by the scant and confusing roles and responsibilities of municipalities (including the eThekwini Municipality) in mitigating the impacts of the virus and proactively responding to the pandemic. The adverse effects of the pandemic to the vulnerable and impoverished communities and the ineffectiveness of the interventions and initiatives to prevent and mitigate the impacts of the COVID-19 in this municipality during the lockdown period, also have influenced this study. This article aspires to dissect the existing prevention, preparedness, and mitigating response and recovery strategies in minimizing the impacts of COVID-19 to the vulnerable communities of eThekwini Municipality, and to analyse the effectiveness of municipal enforcement agencies, operations, institutional arrangements and governance, as well as the efficiency of the response plans to the pandemic. The direct relationship between eThekwini municipality and its Disaster Management Centre is emphasised throughout. Design and research methodology: This paper followed an ethnographic participant observation approach design and research methodology where researchers' experiences and understanding of the vulnerable groups living in the informal settlements and their susceptibility to the COVID-19 pandemic were strategically reflected upon. In addition, a qualitative case study was supported 
by a conventional content analysis through researching and coding media articles from different newspapers and official documents, and reporting on COVID-19 and its effects on vulnerable groups. This study espoused the view that the eThekwini Municipality Disaster Management Centre does not comply with certain crucial sections of the Disaster Management Act and cannot effectively, efficiently and proactively, prevent, mitigate and respond to the coronavirus and its effects. The centre faces a shortage of staff and lacks a qualified workforce capable of achieving the objectives of the centre, a reality that makes them unfit to holistically coordinate the municipal programmes in responding to the slow killer virus. The mass evictions of the people living in the informal settlements by the municipal enforcement agents during the strictly regulated lock-down period, suggest that the municipality is not interested in the health and safety of their residents. This article has a potential impact on the government and its agencies' officials, as it will identify a number of bottlenecks and provide suggestions on their contingency plans in minimizing the impacts of the pandemic. In identifying current research hotspots in the COVID-19 discourse, given the paucity of published data on the application of the disaster management principles, this study will make a valuable contribution.

Keywords: COVID-19, preparedness, mitigation, thematic analysis, multistakeholder recovery strategy

\section{Introduction}

Urban municipalities across the globe are the hotspots of the coronavirus as they are mostly densely populated and home to millions of people living in informal settlements. Friedsen and Pelz (2020) aver that there is one billion of people who are living in the informal settlements across the globe who are mostly vulnerable to infectious diseases. South Africa (with 59 million people) has become the most affected by the SARS-COVID-2 virus in Africa. Furthermore, South Africa is regarded as the most unequal country in the world which is attributed to the legacy of the apartheid. The World Bank (2020) reveals that the same country has a Gini-coefficient of 0.63 with a total of $14 \%$ of people living in the informal settlements without proper houses and sanitation. Statistics South Africa (2020) has recorded the high unemployment rate of $29 \%$ amongst its citizens. Urban informal settlements are also prevalent 
in cities where millions of people reside in densely populated and restricted areas, where the propensity for mass transmission of the COVID-19 cannot be escaped. This has been supported by Wilkinson (2020) and Van Belle et al. (2020) who have written that urban informal settlements have been unable to adhere to unaffordable and unfeasible rules and regulations regarding social distancing and washing of hands. The authors attributed the latter to a geographical nature of such settlements which are densely populated with inadequate access to water and proper sanitation. The difficulties on social distancing in the informal settlements (Masiphumelele and Klipfontein Glebe) has been observed by Gibson and Rush (2020) in Cape Town, where they found that people were unable to effectively execute social distancing. Meanwhile, the shortcomings in infrastructure in the urban informal settlements have been considered as a public health challenge due to the fact that it is difficult to enforce the public health regulations and protocols (Nyashanu, Simbanegavi \& Gibson 2020). There is an existing gap in the literature regarding the role of South African municipalities in curbing the spread of the coronavirus which has necessitated this study. Against this backdrop, this study aspires to determine whether the eThekwini Municipality Disaster Management Centre's (EMDMC) existing structures (including the workforce), and its capabilities in proactively responding to the coronavirus, do comply with the legislations governing disasters at a local sphere of government. The municipality's strategies and approaches on the vulnerable groups living in the informal settlements and their effects on perpetuating the spread of the coronavirus are analysed in this paper. Furthermore, the preparedness of the disaster preparedness and response plans of the municipality to COVID-19 and the bottlenecks in the implementing such plans, are interrogated.

\section{Literature Review}

Numerous researchers (Bong et al. 2020) opine that the novel viral illness which emerged in China in January this year has reached the underdeveloped and developing countries with the most devastating effects being counted and the difficulties of municipalities to respond, noticed and South Africa is no exception. Recently, a number of commentators have written on the coronavirus and made compelling suggestions regarding the approaches and strategies that could be harnessed by municipalities in responding holistically 
to the pandemic, with respect to the people who are living in the informal settlements who are deemed to face high risk. For instance, a policy plan was published by Corburn et al. (2020) identifying ways to reduce the transmission of the virus in the urban informal settlements across the globe, which suggested various interventions by local governments able to arrest the unprecedented spread of the slow killer virus (COVID-19). The authors recommended the development of emergency planning committees, a moratorium on evictions, minimum payments to the poor, community health workers to be dispatched to the informal settlements, including traditional healers (Izinyanga/ Izangoma), the improvement in the access to water and proper sanitation, food support, removal of the solid waste and routes opened for dedicated settlements. An empirical study conducted by Austrian et al. (2020) in Kenya determining the impacts of the COVID-19 transmission as a result of the inadequate basic needs in the informal settlements and overcrowding have provided pertinent solutions. The authors suggested that the communication channels from government should target the illiterate households who are mostly prone to the pandemic. Another interesting study by Nyadera and Onditi (2020) in Kenya (focussing in Nairobi) determined the challenges faced by the slum dwellers during pandemic and concluded that residents in such settlements were directly and indirectly vulnerable to the impacts of the pandemic due to its inadequate planning, poor policies and systematic marginalisation.

A host of researchers (Alirol et al. 2011; Johnston-Robertson et al. 2020; and Neiderud 2015), mention that urban informal settlements are nucleated and overcrowded, with poor access to proper water and sanitation, hence they can be severely affected by the coronavirus. This is why Favas (2020) asserts that such people who are residing in informal settlements are vulnerable to COVID-19. Jarvis et al. (2020) ponder that the lockdown regulations which have been successfully implemented and enforced in the developed world (such as China and Europe), where the virus has been suppressed, can have less success in the urban informal settlements. eThekwini Municipality cannot be considered as an exception. According to Stiegler and Bouchard (2020), the highly regulated lockdown in South Africa experienced serious challenges in the informal settlements including the food supply which has led to the riots and conflicts with the police. The authors posit that restrictions on movements and physical contacts measures are physically unfeasible to apply in the urban informal settlements as they can paralyse the socio-economic conditions of their inhabitants (Dahab et al. 2020). 


\section{Theoretical Framework}

Duze (2016) utilised an empirical research project in an attempt to use its findings as the basis of the creation of an innovative framework instrumental in elevating the levels for disaster risk reduction for municipalities. This was attempted through a case study of eThekwini Municipality. He adopted a case study-based qualitative approach and a semi-structured questionnaire as the main instrument of data collection, and utilised a purposive sampling technique that led to the selection of 41 research participants consisting of three managers of the MDMC, seven eThekwini Municipality Heads of Departments, ten MDMC Disaster Management practitioners and 20 City Councillors. In terms of the findings, interestingly, his most articulated discovery of the effort was the acknowledged absence of a municipal comprehensive disaster risk profile, which could be the foundation of a comprehensive guidance to the multisectoral disaster risk reduction planning. It has been mentioned that such a step forward was forthcoming and it would consist of a ward-based, all-inclusive scientific disaster risk assessment rooted sound procedures because disaster risk assessment is a key mechanism instrumental in achieving the ideals of the existing legislation, rules and regulations (Duze 2016:165).

Another weakness or omission discovered by the researcher was the fact that despite the common knowledge and understanding that municipalities are obligated to strengthen and develop their internal institutional structures and mechanisms in order to improve disaster risk management, the Municipal Interdepartmental Disaster Management Committee that is important in the process of planning, facilitating and coordinating key matters of disaster risk reduction within the municipality, did not exist. This despite the knowledge of the municipal leadership that such a committee is of significance because it is responsible for developing and operationalizing specific and clear terms of reference aligned to those created by the South African National Disaster Management Centre (Duze 2016:166). The researcher emphasised the fact that lack of such crucial internal organisational arrangement undermines disaster risk reduction processes and functional integration and leads to an approach that tends to be fragmented. This reality leads to lack of coordination amongst municipal entities and departments responsible for disaster risk reduction because they lack focus in the coordination between assessment and disaster risk reduction plans (Duze 2016: 167). The non-existence of MDMAF (a Municipal Disaster Management Advisory Forum), a structure that has been highly recom- 
mended by the country's policy and legislative frameworks, is a serious barrier to an analysis and dissection of the multi-dimensional and the multi-sectoral nature of disaster risk reduction. The non-existence of such a body is a barrier to equal stakeholder coordination and integration, a fact that becomes more evident in the lack of technical capacity of staff and funding which are key weaknesses of Municipal Disaster Management Centres. These realities lead to lack of coordination, planning and implementation of disaster risk reduction which is needed, together with intensified capacity building programmes and continuous engagement with political principles and decision makers.

It was interesting that there was unanimous agreement amongst the executives of the eThekwini Disaster Management Centre regarding the lack of sufficient disaster management, a reality that was a serious obstacle to the efficiency of operations undertaken by the centre especially in terms of the focus and implementation of a robust disaster risk reduction agenda (Duze 2016:168). The widely acknowledged lack or 'partial compliance' with disaster management policies and legislation has been described as undermining the progress of systematic well planned and implemented disaster risk reduction programmes. This has been described by the research participants as a reality that exists because of lack of disaster risk assessment profiles and applicable disaster risk reduction plans (Duze 2016:169). The above background sheds light on the dysfunctionality of the EMDMC and the bleak prospect for the effective, effective and proactive response to the coronavirus and worse, to the people living in the informal settlements.

\section{Research Approach}

This is a qualitative paper that has adopted a participant observation method (Shah 2017), aimed at determining the COVID-19 effects on the socioeconomic conditions of vulnerable groups who are living in informal settlements within eThekwini Municipality. The participant observation produces new knowledge which has been silenced (in the case of the living conditions of the people residing in the informal settlements) pre and during the COVID-19 pandemic. The new theory is produced in this article and realised in action as researchers have long-term engagement (long-duration) with the group of people in the informal settlements. Furthermore, the researchers have a deep understanding of the group of people and their social processes as they grew up in informal settlements, conducted empirical 
research studies in such settings and has also been observing their social lives over the past 40 years (Shah 2017). This study has been shaped by researchers' experiences and understanding of informal settlements - those who are prone to the detrimental effects of the coronavirus. Themes which guided this study were identified and questions set. This approach is appropriate as the researchers looked back and examined the past in order to learn from history and to gain knowledge from challenges experienced, thereby assisting in continuous improvement of the discourse.

A qualitative content analysis has also been followed in this study. Research was conducted into the communicative characteristics of language by focusing on COVID-19 content and its effects on the socio-economic conditions of people and businesses, the underlying themes and the meaning of the texts examined. A conventional content analysis was followed in this article, with the coding categories being derived from the text data (Bryman 2014).

A thematic analysis was chosen and used in this paper as the analysis is not associated with a specific philosophical orientation. The patterns and themes that emerged from the data set were identified, analysed and described. Furthermore, a thematic analysis was used in order to interpret features of COVID-19 and its effects (Braun \& Clarke 2006).

\section{Context of COVID-19 in South Africa}

International and national studies (Corburn et al. 2020; Duze 2016; Ngcamu 2011) have shown conclusively that the careful planning and implementation of a sound disaster management framework is the key to the protection of communities, especially vulnerable communities, through the rigorous application and implementation of disaster preparedness, mitigation and prevention. On 5 March 2020, the NICD confirmed the first COVID-19 case in the country (NICD 2020). The first victim was travelling from Italy to Johannesburg. On 11 March 2020, a traveller, having visited Germany, Switzerland, Austria and Turkey, was confirmed to be the first case in the Western Cape (Parker et al. 2020:4). When the number of infected South Africans reached 51 on Sunday 15 March 2020, the declaration of a national state of disaster signed by the COGTA Minister of Cooperative Governance on the March the $15^{\text {th }} 2020$ was based on the severity and magnitude of COVID-19 outbreak. The Minister followed Section 3 of the Disaster Management Act 2002 (Act No. 57 of 2002) (RSA 2002) and in terms of - 1) 
Section 27(1) of the Act declared a national state of disaster. The Act was considered necessary for the realisation of personal and property protection, relief provision and assistance for the public against the effects of the pandemic (RSA 2020).

\section{The eThekwini Disaster Management Set-up: The Present Realities and the Coronavirus Conundrum}

Disaster possibilities, challenges and realities not only in KwaZulu-Natal but throughout the country, are acknowledged in the South Africa's Constitution (RSA 1996:114) as being the legal responsibility of the state that is obligated to provide appropriate disaster management services rendered as a service to all the country's people. As the well-being of all people is the most important priority of the state, all layers of the government are obligated by law to protect all citizens, communities, the environment, state and private property and for all these, there is always the need for safety against disaster. This begins with plans and implementation of disaster risk reduction, mitigation of climate change and continuous effort on the part of state and government institutions to aim at the reduction of the vulnerability of all people, existing and future infrastructure and all other national assets (RSA, 1996:114).

In supplementing the country's Constitution, Section 53 (1) of the Disaster Management Act (RSA 2002: 61) makes local government responsible for the preparation of customised plans and regular reviews of plans in ensuring that they deal efficiently, effectively and continuously with all matters related to disaster management, with special emphasis on disaster preparedness, prevention and mitigation. The above section has been supplemented by Sections 43 and 44 of South African Disaster Management Amendment Act No. 16 of 2015 (RSA 2015), which states that every municipality is responsible in its management capacity to establish, plan, and implement disaster management functions. In this process, it is the responsibility of local government to strive for a synchronised, well-planned and cohesive method in disaster management with disaster risk deduction as a fundamental objective through the utilisation, cooperation, coordination and synergy amongst all relevant departments and sections of the municipality. Within this context, the Disaster Management Act of 2002 supplements dictates of the Local Government Municipal Systems Act No. 32 of 2000 (RSA 2000), which includes clauses indicating the requirement of disaster 
management plans to be organically integrated into preparation processes of the Integrated Development Plan (IDP) of every municipality. The unifying combination of commitment in the most fundamental biding document in the local government terrain is rooted on the legal objective of guaranteeing the reduction of the possibility of disaster risk and vulnerability. On paper, eThekwini seems to possess a well-equipped response and recovery capacity in terms of disaster management and the municipal structures are made of Cluster Deputy City Managers who report to the City Manager while the Heads of Units report to specific Cluster Deputy Municipal Managers. In general terms, Departments report to the Heads of Units. There is a general feeling recorded in the official documents of the municipality that the 'past response' points to the fact that the entity believes that it is ready and able to deal with incidents of a 'major emergency or disaster scale' (eThekwini Municipality 2020:941). The Disaster Operations Centre (DOC) leads the overall coordination of response with the support of the CCTV Operations Room and the Units Emergency call centre.

There is a large number of internal and external departments that become activated when there is the need for mobilisation planning and action. There are also standby rosters that ensure that all services are continued when the DOC is activated, as it aims to provide an efficiently run operational environment that facilitates all existing agencies to function effectively and cooperatively under all circumstances so that strategic decisions can lead to solving problems in the response to existing or impending disasters or emergencies. The key function of the DOC is to direct the management of resources and deployments at all levels by identifying the priorities and the existing dynamics of complicated incidents. Thus, the function and processes undertaken allow the required shift in controlling the co-ordination dynamics of the response activities from one agency/section to another. There are more than 700 staff members in the Disaster Management Centre who are divided into the main sections, consisting of the Disaster Management Operations, CCTV and the Call Centre. According to the Integrated Development Plan of the eThekwini Municipality, the Disaster Management Operations occupy 15 dedicated staff members who are responsible for disaster responses exclusively and the centre has a database of over 600 disaster volunteers living in the most vulnerable municipal wards of Durban, who are deployed to a number of disaster management functions when needed; all disaster response efforts involve a very wide variety of internal and external stakeholders. The list of 
internal stakeholders involved in disaster is based on 19 entities including Security Management, EMACC (the Emergency Mobilising and Communication Centre), electricity and engineering services, the fire and emergency services, the Health and Human Settlements departments, the Metro Police, the Parks, Recreation and Culture Departments, the City Fleet and the Community Participation and Action Support (eThekwini 2020: 942). The external stakeholders include NGOs, Community- Based Organisations, religious organisations, the Departments of Social Welfare, Health, Agriculture and Education, Transport RTI (Road Traffic Inspectorate), the South African Police Services (SAPS), Emergency Medical Services, technical specialists, academics, the South African Weather Services (SAWS) and the Disaster Command Vehicle that serves as a mobile disaster operation centre responsible for onsite strategic coordination. It is basically used as a Venue Operations Centre for major incidents, disasters and for the safety management of events. There are at present two satellite Centres at Pinetown and Verulam that have a 24/7 call centre and CCTV monitoring at areas of high risk. They are fully equipped and function independently (eThekwini 2020: 942-943).

Despite the official presentation of the leadership and staffing of the municipality's Disaster Management Centre in the entity's official documents, the realities facing its structures, functions and limitations were exposed publicly on a number of occasions, beginning during the first days following the devastating storms that hit Durban's townships in mid-March 2019, which left a trail of destruction as a number of wards were badly affected. However, most of the damage took place in the northern regions, such as Inanda, KwaMashu, Ntuzuma, Phoenix and Verulam. While experts estimated the cost at R50 million, there was a general feeling that the Disaster Unit was in fact a 'disaster on its own' because it had not throughout the years assessed flood prone areas throughout the city wards and had not updated its Disaster Risk Assessment for the municipality. During the public debates, a municipal firefighter openly declared that there was no plan to deal with the heavy rains and their repercussions for the infrastructure, while the Chairperson of the Human Settlements and Infrastructure Committee of the municipality stated that the city would be discussing interventions to respond more effectively to disasters, build alliances with NGOs and train communities to act on disaster relief interventions before they occur and to be educated about how drains get blocked. Following the devastation of the floods, all items distributed to displaced victims mainly consisting of 400 blankets 200 mattresses and hot 
meals for a hundred people were donated by Muslim organisations and the Red Cross (Pillay 2019a). However, a research study conducted by Ngcamu and Wallis (2011) in the Kennedy and Foreman informal settlements in Durban revealed the majority of the respondents as receiving the humanitarian assistance from the NGOs and the civil society groups, as compared to the eThekwini Municipality, in the aftermath of disasters.

KwaZulu-Natal and eThekwini Municipality have been over the last decade facing a wide range of very serious disaster risks that are the result of a multiplicity of weather and human factors and actions, as the ever-increasing realities of climate change and global warming lead to a wide variety of effects associated with dangerous, severe and hazardous conditions that lead to human vulnerability throughout society and communities. Populations throughout the world and especially their most vulnerable sections, face a wide variety of disasters that put thousands of lives at risks, but simultaneously create serious socio-economic setbacks and disadvantages to the poor and marginalised sectors and communities. In most instances, such phenomena have detrimental repercussions for physical and natural physical resources upon which human beings depend for their own life and survival. Hence Wilkinson (2020) has recommended the combination of the public health and socio-economic interventions should be balanced. The author further maintains that the local residents in such settlements who have an unsurpassed knowledge of the area should partner with municipalities in the development of appropriate control strategies.

Within such an environmental challenge, eThekwini Municipality has over many years experienced a continuous, even relentless, increase of disaster risks and catastrophes at a number of levels. Such disasters take place within a physical environment where a substantial segment of the population lives under poor, congested, and unhygienic conditions that are seriously fragile ecologically as in the case of the many informal settlements within the municipality. In one of the latest disasters that lasted from November 2019 to January 2020, more than 3148 houses were completely destroyed and 5632 were damaged. Close to 30000 people were affected. There was a confirmation of 44 fatalities and 193 injuries recorded due to the devastation by summer storms, including massive rainstorms and tornados (Singh 2020). A total of 445 incidents were reported to the disaster management centres in the province during that period, showing the consequences of extremely fatal thunderstorms, strong winds and heavy rainfall, and including very serious 
damages that took place during the festive season of Christmas and the New Year. These incidents included 133 structural fires, 112 incidents related to strong winds, 108 incidents of extremely heavy rainfall, 67 related to lightning, 19 hailstorms and 8 drowning. 99 schools in the province (KZN) were damaged by storms during this period.

Ngcamu (2011) utilised the case study of two heavily populated informal settlements in Durban (situated in Kennedy and Foreman roads) and the role of disaster management in case of fires, a disaster that has been very frequent in the city's vulnerable areas. His empirical effort concentrated on the analysis and dissection of existing or absent processes and structures instrumental systemic and/or functional operations associated with preparedness, response, prevention, recovery and rehabilitation, as well as the repercussions related to implications related to finances, functional and institutional responsibilities and future expectations.

His study utilised a dual approach consisting of a qualitative approach in the data analysis obtained from interviews with eThekwini Municipality officials working directly or indirectly in various fields of disaster management and communities. The interviews conducted with the municipal officials included a variety of disaster management strategies and research variables including attitudes, knowledge and opinion in respect of functionality of disaster response, mitigation, preparedness, recovery and rehabilitation (Ngcamu 2011:130). The purposive sample of eThekwini Municipality officials included nine senior municipal managers in the disaster management terrain, including planning, housing, infrastructure, fire services, electricity, revenue, safety and security and a ward elected politician (Ngcamu 2011:137).

The researcher's findings pinpointed the existence of a wide variety of important relations and connectivity within the spectrum of the existing variables fundamental in the understanding of the existing realities of disaster management initiatives, successes and/or failures in cases of fires in informal settlements. The research pinpointed the existence of a number of weaknesses associated with the processes of the municipal centre of disaster management. Such weaknesses were mainly evident in the existing operational framework and planning of disaster management that has been implemented when fires occur, especially in the case of informal settlements. Urban locations, because of the existing realities, are difficult terrains for operations, mainly because fires have occurred frequently in the last few years. The findings led the researcher to the conclusion that the municipal political and administrative 
leadership need to develop a classification of a system or systems associated with hazard mitigation strategies. These categories should be directly and indirectly related to community protection, hazard control, practices of building construction, protection of building contents and land-use practices. The non- existence of the recognition of recovery period mitigation and incorporation of such an objective into recovery planning was also mentioned as a key structural and functional challenge.

A study by Dludla (2016) also related to the levels of effective mobilisation of the eThekwini's disaster management machinery and reduction strategies in cases of fires with the Clare Estate informal settlements as a case study. It was a qualitative study utilising the case study method and a judgmental sampling frame that led to a wide array of responses regarding a disaster risk reduction strategy. The sample consisted of a number of 12 staff members in the municipality's disaster emergency and control unit, the fire management unit and fire fighters, five activists from the civil society movement Abahlali Base Mjontolo, and eleven residents from the Clare Estate informal settlements. Basically, the study revealed that the relevant unit of the Disaster Management Centre is seriously understaffed and this reality has been instrumental in hindering the fundamental processes that ought to be carefully planned, implemented and enforced according to the city's plan for preventing a fire. Interviewees acknowledged that the existing official Disaster Centre organogram is misleading in terms of existing posts and number of staff, as the reality is that there is a complete discrepancy in terms of the department's employee numbers. This means that it was acknowledged, that while there are a number of disasters occurring around the eThekwini municipality, the entity employs a small number of people who are unable to attend to them. The Department's senior officials expressed the view that the key challenge faced by the leadership is the lack of a budget that would facilitate the employment of new staff. This was the concern shared by all members of the municipal staff who were interviewed including those officials working in the Fire Department.

\section{Non-compliance to the Legal Prescripts on Disaster Management}

It became evident in the audit report that the Municipal Disaster Management Advisory Forum only had a meeting in November 2015 and its functions have been inadequate for years while there was no functionality in the E-Sponder 
system, an incident-reporting system. The eThekwini Municipality Disaster Management Centre's malfunctioning of the Disaster Management Advisory Forum contravenes section 51(2) of the Disaster Management Act, which opines that the role-players represented in the Forum must consult each other and coordinate their actions and plans on matters regarding disaster management within a municipality. Various role-players are enshrined in section 51(1d), who form part of the Forum as designated by the mayor which includes the organised business and labour, CBOs, traditional leadership, academic institutions, insurance industry, agricultural sector, medical, specialised organisations (scientific and technological and other civil society groups for relief) are non-existent during the scourge of the COVID-19 pandemic. One of the staff members in the Centre indicated that while the 2019 first quarter audit report pinpointed a number of worrying realities, there were in fact discrepancies which were outlined in the meetings where the report was debated. This, it was argued, was because of the fact that the disaster management plan in existence suffers from a number of things, because despite that it is extensive and detailed, it could be classified as outdated given the new climate and disaster realities, but also because when emergencies arrive the plan is not implemented. It was said that the reality was that the early warning systems and processes were not implemented in the 2017 floods, or in April 2019 flood disaster, which proves the point. Such issues have been outlined in the audit committee's report which also found that future early warning systems had not yet been fully implemented, especially in terms of real-time forecasting of droughts, floods, and seasonal changes. The bleak picture painted above has been supported by the municipal councillors from the opposition political parties (IFP and DA), that the Disaster Management Centre is a disaster on its own and that the disaster management plan is not implemented during emergencies and disasters. The non-implementation of the disaster management plan by the municipality is in contrast with Section 53(1a,b,c) of the Disaster Management Act as it mandates all municipalities to conduct disaster risk assessment and risk identification and mapping of communities and households who are vulnerable to physical and humaninduced threats (COVID-19 is not an exception). Section 53 (ad) further posits that the municipalities should coordinate and align the implementation of the organs of state and the role players. To make things even worse, while the KZN provincial government allocated over R600 million to eThekwini to assist residents affected by disasters that occurred between October 2017 and April 
2019, it became evident that the municipality failed to spend R46 million allocated in the last financial year. This means that the municipality failed to implement disaster relief programmes and it could not be allocated more funds from the provincial government because of the unspent budget. This occurred in most of the 10 municipalities involved (Duma 2019).

A number of the visible and known weaknesses of eThekwini's Disaster Centre are honestly outlined in the municipality's Integrated Development Plan and include inadequate resource allocation, language limitations in communication strategies and implementation, absence of efficient supervision, backlog in terms of Disaster Management Centre human resources capacity and strain on existing resources, insufficient funding and staff, lack of infrastructure services (utilities) to informal settlements, inability to provide full requirements of the Act due to lack of more experienced and sufficient staff, and the lack of an integrated response to incidents (eThekwini 2020:943).

\section{EThekwini Municipality Disaster Management Centre}

The latest disasters a few months before the pandemic reality of the great weaknesses of the Disaster Management Unit were exposed as the Municipality's audit committee officially and openly declared that the city was seriously ill-equipped to respond to natural disasters. This was because of the lack of staff and the failure of the leadership and the municipality at large to recruit volunteers. The absence of early warning systems exacerbated the problems. One of the stalwarts of a Durban-based environmental nongovernmental organisation, stated that for a municipality that has major environmentally and nature-based disaster problems since the late 1990s not to have an 'emergency plan', is a clear indication that it is a city that does not take climate change seriously. He produced documents showing correspondence with eThekwini's leadership dated as far back as 1998 requesting the municipality to produce an emergency plan to no avail. It was stated that the 2019 devastating disasters were on-going. The new challenges related to the Corona pandemic are an emergency of major proportions and it is a great pity that 'no one knows where and when to run'. The question thus remained although there is enough staff, much infrastructure and above all, a very big budget, but how are the people, especially the poor, the marginalised and the vulnerable, to be safeguarded? All these serious questions were directly related 
to the April 2019 floods and the devastation later that year, that resulted in tens of deaths and wounded and thousands of homeless and displaced people as well as a damage of over R 1 billion.

A municipal first quarter audit report indicated that the Disaster Management Unit was unable to meet its objectives effectively and efficiently because its staff resources were 'inadequate'. The report indicated that by March, while only 11 out of 85 posts had been filled, only 21 out of 110 wards in the city had volunteers to help in the event of a disaster. This reality showed conclusively that the municipality has violated section 54 of the Disaster Management Act which deals with the disaster management volunteers. Section 58 (1) of the Disaster Management Act indicate that a metropolitan (eThekwini in this case) must establish a unit structure for the volunteers to partake in disaster management within a municipal area. Subsection 2 of the same section suggests that anyone who meets the requirements may apply to enrol as a volunteer and that the National Disaster Management Centre (NDMC) must maintain the database of the registered volunteers (subsection 3a) and that volunteers can participate in exercising related to disaster management (subsection 4). The transgression of the previous prescript suggests that the municipality has failed to harness on the available workforce with various talents and skills at their disposal in order to proactively respond to the COVID-19 pandemic. The bottom-up approach is essential in such health-related disasters where volunteers who are active in societies and to all wards and communities and committees as they work at a grassroots level with various stakeholders, CBOs, NPOs, communities and households. The volunteers who are trained to be impartial can play a pivotal role in responding and mitigating the impacts of the spread of the slow killer virus. Furthermore, the volunteers can perform a myriad of activities in ensuring that there is a smooth communication between the municipality and affected communities who are mostly affected and infected by this slow killer virus. The volunteers can also identify the needy designated groups and direct the humanitarian assistance to the indigent persons who are at high risk during the COVID-19 lockdown period. The Report also indicated that in the various suburbs and wards of the municipality, both recruitment and training of potential volunteers were incomplete, and the responsible committee discovered that records of training were not available for audit (Pillay 2019b).

A Municipal Councillor was adamant that the politicians 'who really cared' knew the real situation in the Disaster Centre and the various 
departments, sections and entities both internal and external that were integral components of its success in all aspects of their duties and responsibilities. The position was that much smaller local municipalities with less expertise, funds and staff had better plans when compared to eThekwini, the only Metropolitan entity in the province. This was, it was said, because even having their own functional and financial problems these municipalities had better plans, as their response to disasters (Pillay 2019b). This was said because the eThekwini leadership 'centrally' do not seem to understand the importance of the Disaster Centre and the municipality's own audit committee findings and recommendations. The truth that there were key vacancies in the Department that were not filled was acknowledged as a key step backward. This meant that the executive council throughout the years have approved millions of rand in order to assist people affected by disasters, but there are not enough and welltrained staff able to ensure that the funds are distributed to people, communities and groups who really need them. Plans are discussed, agreed upon, planned and implemented, but there is no one to ensure that this implementation is the one that it was approved. The recent developments on the malfunctioning the EMDMC is reminiscent on an empirical and pioneering study conducted by Ngcamu and Wallis (2011), which aimed at contributing to the formulation of the disaster management policy and plan, efficient and effective EMDMC which is central on the disaster management plan. The researchers concluded that the planning policies fail dismally to assist the densely populated informal settlements from the impacts of disasters. Ngcamu and Wallis (2011) further asserted that the municipality does not allow those living in the shacks to formalise their houses which makes people unsafe from any form of disaster. The study by these authors recommended the municipality to comply with the Disaster Management Act as it contravened the latter prescript in its totality. For instance, the authors mentioned that the eThekwini Municipality disaster management policy, plan, centre and frameworks were non-existent as mandated by the Act.

\section{Government's Hypocrisy and Municipal Defiance}

The South African municipalities have embarked on mass illegal evictions, abuse, victimisation and attacks on the informal dwellers in the advent of the highly regulated Level 5 period which restricted movements and enforced the distancing of people, all very impractical in such settlements. During this 
quarantine period, eThekwini Municipality has illegally evicted informal dwellers in various parts of eThekwini Municipality which made them susceptible to be infected by the slow killer virus and the subsequent high transmission of the virus throughout the country. This is happening while municipalities (including eThekwini Municipality), are hard hit by the virus without human capabilities and measures to reduce infections in the disaster management centres. This is perpetual at the eThekwini Municipality as, long before the COVID-19 pandemic, its Disaster Management Centre (EMDMC) has been dysfunctional, due to shortage of staff generally and especially qualified workforce; a disaster management plan that is partially implemented and an advisory forum that is ineffective or non-existent. Meanwhile, eThekwini Municipality is amongst the seven metros that were declared on the 28 May 2020 by the Minister of Co-operative Governance and Traditional Affairs as hotspots in the country for the coronavirus (Government Gazette. No 43364). The additional cities include Tshwane, Johannesburg, Ekurhuleni, Nelson Mandela Bay, Buffalo City and Cape Town. The eThekwini Municipality's culture of a top-down approach and manner of dealing with the economically vulnerable informal dwellers as non-citizens, increase the likelihood of spreading of the coronavirus to such marginalised areas. Furthermore, the civil society groups, non-profit organisations (NPOs), faithbased organisations (FBOs), relief organisations, traditional leaders and health specialists have been marginalised in the response on the COVID-19, although such a step is contrary to the Disaster Management of 2002 (Act 57 of 2002) as amended in 2015 (Act16 of 2015).

The eThekwini Municipality DMC has compromised the already compromised city due to its inadequate response to the COVID-19 pandemic. The government's lockdown strategy and regulations during the coronavirus have been strong on physical distancing, which is impossible in the nucleated informal settlements located within eThekwini Municipality. This is exacerbated by the eThekwini Municipality's victimisations, attacks by the municipal agents, evictions and demolitions of the shack settlements during the lockdown period. The municipality undertook the process to evict the the poor and marginalised surviving mostly in the informal settlements, during the COVID-19 pandemic which makes the DMC complicit as they form part of the municipal Community and Emergency Services cluster. This cluster is a decision-making body which also deals with evictions. The DMC falls under the eThekwini Municipality Disaster Management and Emergency Control 
Unit. This is happening in the advent of the lockdown and a clear statistical knowledge that the eThekwini Municipality is home to a total of 550 informal settlements with 226000 inhabitants (eThekwini Municipality, Tuesday, 01 August 2019), which is mostly susceptible to fires (normally called shack fires), natural disasters, criminal businesses, unlawful evictions, drug and human trafficking, and informal business which are owned by the shack landlords. The majority of the settlements are illegally occupied and built on the municipal, private companies' or individuals' land. In response to the COVID-19, eThekwini Municipality has embarked on evictions and demolitions projects of the informal settlements in selected areas within eThekwini Municipality.

Figure 1: Evictions by eThekwini Municipality

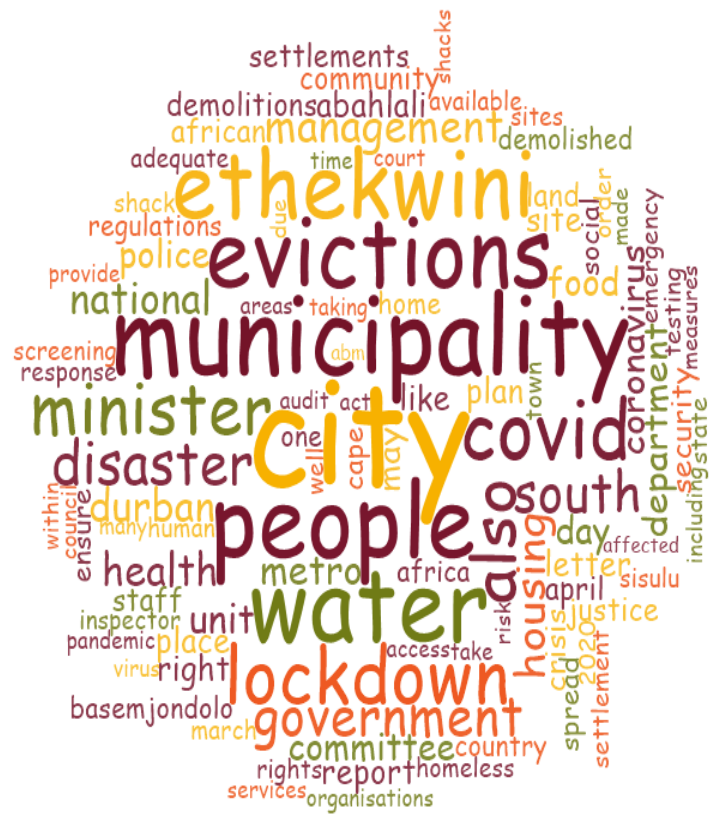

Source: The Authors

According to Pikoli (6 April 2020), the Abahlali BaseMjondolo which campaigns both against evictions and for adequate public housing, was cited 
as indicating that the evictions were unlawful. Such uncalculated evictions happen despite the escalation of the coronavirus on the vulnerable informal settlements that are densely populated, overcrowded and lacking of basic services. Calculated and risky moves by the eThekwini Municipality can be attributed to the revenge directed to the informal settlements' residents who openly vote for the opposition parties during the election seasons. Such analogy can be supported by an investigation by Ngcamu and Wallis (2011) within eThekwini Municipality on the strategies and capabilities of the metro in responding to disasters in the prominent informal settlements (Foreman and Kennedy Road). These authors argued that these settlements receive too much political interest from the local politicians as they play a deciding factor during elections in Ward 25 and beyond.

Such evictions are contrary to the government's moratorium on evections as outlined by the Minister of Justice (Figure 1). However, the prevalence of evictions in the informal settlements was instituted by eThekwini Municipality despite the explicit prohibition of evictions under Alert Level 5. This was evident in Cato Crest in Durban, where a total of 14 homes were demolished by a company (Calvin Family Security Services) contracted by eThekwini Municipality. The Socio-Economic Rights Institute (SERI) representing the informal dwellers challenged the persisting evictions and the Court interdicted the municipality and its land invasion unit to ease on evicting and demolishing the informal settlements inhabitants. 'However, eThekwini Municipality continued to evict squatters from homes without a court order and SERI filed an urgent application in the High Court for an interdict, contempt and compensation for the damage to property and the matter was settled on the 24 April 2020, where the City undertook to refrain from demolishing, burning and removing informal structures. In the aftermath of the court order, the informal dwellers continued to experience victimisations, abuse and violence from the City. The unlawful evictions of the informal dwellers by eThekwini Municipality in the face of the slow killer virus (COVID-19) has violated section 26(1) of the Bill of Rights, which states that every person has a right to access to proper housing.

Section 36 of the Government Gazette (No 43364) (1) Subject to subregulation (2), states that:

A person may not be evicted from his or her land or home during the period of Alert Level 3 period. 
(2) A competent court may grant an order for the eviction of a person from his or her land or home in terms of the provisions of the Extension of Security of Tenure Act, 1997 (Act No. 62 of 1997) and the Prevention of Illegal Eviction from and Unlawful Occupation of Land Act, 1998 (Act No. 19 of 1998): Provided that an order of eviction may be stayed and suspended until the last day of the Alert Level 3 period, unless a court decides that it is not just and equitable to stay and suspend the order until the last day of the Alert Level 3 period.

In addition, the Municipality also violated subsection 3 of the Section 26, which clearly states that no one should be evicted or their houses demolished without an order of the court. As the Republic of South Africa is a signatory of the Universal Declaration of Human Rights which emphasises persons having a legitimate right to the standard of housing and the basic needs and primary health care (Article 25), the eThekwini Municipality has violated the latter. Hence, Corburn et al. (2020) have cited realities in the informal settlements which might perpetuate the transmission and spread of the coronavirus which is the lack or non-existence of the basic needs, space constraints, violence and over-crowding. Such violations have triggered a host of the non-profit organisations (SERI, Rights2Know Campaign) to legally challenge the eThekwini Municipality on flouting the lockdown regulations and the city, endangering their vulnerable communities in the COVID-19 pandemic. This also forced SERI to refer the municipality as a 'gangster' and 'rogue' organisation (Zukiswa Pikoli, 6 April 2020).

Grobler (22 April 2020) argued that it is illegal and an offence to evict people during the national lockdown which is against the spread of the coronavirus. Meanwhile, Louise du Plessis, the head of the land and housing programme at Lawyers for Human Rights, was quoted from the News24 newspaper (Grobler, 22 April 2020) as saying that:

Destroying homes where people already live is illegal. There is no way people can be evicted if they already live in those structures - not without a court order. For now, the government cannot touch them. They can bring an application after the lockdown and have them evicted then.

The aforementioned was also echoed by the government representative in the 
Presidency who said that it is unfortunate and inappropriate to evict people during the Covid-19 lockdown:

The evictions glaringly diminish the intentions of the lockdown and expose already vulnerable people to Covid-19 and other harmful elements such as crime and rainy weather. When the president and the executive announced that there will be no evictions, we understood that those instructions would be respected by all. It is therefore unacceptable that municipalities have undermined the spirit of the lockdown and have shown clear disdain and lack of empathy for the people, especially the poor. We urge the municipalities to desist and refrain from any planned evictions henceforth, and to abide by the regulations.

The eThekwini Municipality is becoming a law unto itself and disobeying the national government's instructions on putting the restrictions on evictions, which suggests that the safety of vulnerable people to the deadly virus comes second to politics.

\section{Conclusion}

The eThekwini Municipality disaster management centre's effectiveness, efficiencies and capabilities as well as its compliance to the prescripts governing disasters are interrogated in this paper, as is their lack of proactive response to the coronavirus. The municipality's conduct in dealing with the most vulnerable people living in the informal settlements is analysed and the potential effects on the spread of the coronavirus. Notably, the EMDMC, which is responsibly to proactively coordinate and respond to any kind of disaster (including the coronavirus), does not comply with the Disaster Management Act of 2002. A host of the structures (plans, frameworks, forums) are non-existing and/or are malfunctioning, which makes vulnerable communities mostly living in the informal settlements even more vulnerable to the COVID-19 virus.

It is noteworthy that the centre is dysfunctional as there is a shortage of resources (financial and human) and a shortage of qualified staff who can proactively achieve the goals of the EMDMC thus mitigating the impacts of the virus. The reactionary approach of the centre is exacerbated by its 
approach, which is characterised by diminished focus on disaster risk assessment and reduction and the non-involvement of other departments, sectors and stakeholders in taking a holistic response approach to disasters.

The mass evictions and victimisations of the people living in the informal settlements during the strictly regulated lockdown by the eThekwini Municipality agents is the last straw which makes them complicit in the uncontrollable spread of the coronavirus within the eThekwini Municipality residents and beyond. eThekwini Municipality has violated fundamental human rights as enshrined in the supreme constitution of the country: it ensured that the well-being its residents, of people, follow politics.

This paper concludes that in view of the above, EMDMC is incapable in managing the current slow killer disaster and it is suggested that provincial disaster management centre should intervene, re-engineer and overhaul the operations of the centre. The provincial government should administer the operations of the centre and employ persons with relevant competencies to ensure that the city complies with the Disaster Management Act.

Due to the COVID-19 lockdown regulations on movements, the researchers relied on secondary data and it is recommended that future researchers employ other designs and methods in order to test the themes which emerged in the findings of this study.

\section{References}

Alirol, E., L. Getaz, B. Stoll, F. Chappuis \& L. Loutan 2011. Urbanisation and Infectious Diseases in a Globalised World. Lancet Infectious Diseases 11,2:131 - 41. Available at:

http://dx.doi.org/10.1016/S14733099(10)70223-1(Accessed on 09 April 2020).

Austrian, K., J. Pinchoff, J.B. Tidwell, C. White, T. Abuya, B. Kangwana, R. Ochako, J. Wanyungu, E. Muluve, F. Mbushi \& D. Mwanga 2020. COVID-19 Related Knowledge, Attitudes, Practices and Needs of Households in Informal Settlements in Nairobi, Kenya. Available at: https://www.dailymaverick.co.za/article/2020-04-06-demolitions-and-

evictions-the-ethekwini-council-has-gone-rogue/

(Accessed on 09 April 2020.)

https://doi.org/10.2139/ssrn.3576785 
Bong, C.L., Brasher, C., Chikumba, E., McDougall, R., Mellin-Olsen, J. \& A. Enright. 2020. The COVID-19 Pandemic: Effects on Low-and MiddleIncome Countries. Anaesthesia and Analgesia 131,1: 86 - 92, April 1. Available at: https://doi.org/10.1213/ANE.0000000000004846

PMid:32243287 PMCid:PMC7173081 (Accessed on 26 June 2020.)

Braun, V. \& V. Clarke. 2006. Using Thematic Analysis in Psychology. Qualitative Research in Psychology 3,2: 77 - 101. Available at:

https://doi.org/10.1191/1478088706qp063oa (Accessed on 23 April 2015.)

Bryman, A. 2014. Samhällsvetenskapliga metoder [Social Science Methods]. Stockholm: Liber.

Corburn, J., D. Vlahov, B. Mberu, L. Riley, W.T. Caiaffa, S.F. Rashid, A. KO, S. Patel, S. Jukur, E. Martínez-Herrera \& S. Jayasinghe 2020. Slum health: Arresting COVID-19 and improving well-being in urban informal settlements. Journal of Urban Health 1-10.

https://doi.org/10.1007/s11524-020-00438-6

PMid:32333243

Dahab, M., K. van Zandvoort, S. Flasche et al. 2020. COVID-19 Control in Low-income Settings and Displaced Populations: What can Realistically be Done? Conflict and Health 14: 54. Available at:

https://doi.org/10.1186/s13031-020-00296-8

(Accessed on 12 May 2020.)

Disaster Management Act No.57 of 2002. Available at:

http://www.ndmc.gov.za/portals/0/WebDocuments/Guidelines/DM/dow nloads/SJ\%206\%20DM\%20Act\%2057-02.pdf

(Accessed on 8 May 2015.)

Disaster Management Amendment Act 16 of 2015. Available at:

https://www.gov.za/documents/disaster-management-amendment-act16-2015-15-dec-2015-0000

(Accessed on 24 February 2017.)

Disaster Management Act: Regulations: Alert Level 3 during Coronavirus COVID-19 Lockdown. Government Gazette (No 43364).

Dludla, B. 2016. Effectiveness of the eThekwini Municipality Disaster Risk Reduction Strategy Pertaining to Fires at Informal Settlements: A Case of Clare Estates Informal Settlements in South Africa. Master of Public Administration School of Management, IT and Governance, University of KwaZulu-Natal. 
Duma, N. 2019. DA Calls for Accountability over Unspent Disaster Relief Funds in KZN, EWN. 21 November. Available at:

https://ewn.co.za/2019/11/21/da-calls-for-accountability-over-unspentdisaster-relief-funds-in-kzn

(Accessed on 22 March 2020.)

Duze M.P. 2016. A Framework for Disaster Risk Reduction for Local Government: A Case Study of eThekwini Municipality, Master of Public Administration School of Management, IT and Governance, University of KwaZulu-Natal.

eThekwini Municipality Tuesday, 01 August 2019. Informal Settlement Upgrading in Durban.

eThekwini Municipality 2020. Integrated Development Plan. 5 Year Plan: 2017/18 to 2021/22. Durban

Favas, C. 2020 Guidance for the Prevention of COVID-19 Infections among High-risk Individuals in Urban Settings. Available at:

https://www.lshtm.ac.uk/media/35726

(Accessed on 11 November 2020.)

Friesen, J. \& P.F. Pelz. 2020. COVID-19 and Slums: A Pandemic Highlights Gaps in Knowledge About Urban Poverty. JMIR Public Health and Surveillance, 6(3), p.e19578.

https://doi.org/10.2196/19578

PMid:32877347 PMCid:PMC7486000

Gibson, L. \& D. Rush 2020. Novel coronavirus in Cape Town informal settlements: feasibility of using informal dwelling outlines to identify high risk areas for COVID-19 transmission from a social distancing perspective. JMIR Public Health and Surveillance 6,2:p.e18844.

https://doi.org/10.2196/18844

https://doi.org/10.1186/s12916-020-01597-8

Grobler, R. 22 April, News24. Is it legal to evict anyone during lockdown? No, say legal experts. Available at:

https://www.news24.com/news24/southafrica/news/is-it-legal-to-evictanyone-during-lockdown-no-say-legal-experts-20200422 (Accessed on 23 April 2020).

ICRC. Displaced in Cities 2018. Available at: https://shop.icrc.org/displacedin-citiesexperiencing-and-responding-to-urban-internal-displacementoutside-camps2822.html? store $=$ default 7

(Accessed on 19 May 2020.) 
Jarvis, C., K. Zan Vandvoort, A. Gimma, K. Prem, P. Klepac, G.J. Rubin et al. 2020. Quantifying the Impact of Physical Distance Measures on the Transmission of COVID-19 in the UK. BMC Medicine 18: 124. https://doi.org/10.1186/s12916-020-01597-8

(Accessed on 7 April 2020.)

PMid:32375776 PMCid:PMC7202922

Johnstone-Robertson, S.P., D. Mark, C. Morrow, K. Middelkoop, M. Chiswell L.D.H. Aquino et al. 2011. Social Mixing Patterns within a South African Township Community: Implications for Respiratory Disease Transmission and Control. American Journal of Epidemiology 174,11:1246 - 55. Available at:

http://aje.oxfordjournals.org/ https://doi.org/10.1093/aje/kwr251

PMid:22071585 PMCid:PMC3224253

Neiderud, C-J. 2015. How Urbanization Affects the Epidemiology of Emerging Infectious Diseases. Infection, Ecology and Epidemiology 5,1:1

- 9. Available at: https://doi.org/10.3402/iee.v5.27060

(Accessed on 7 April 2020.) PMid:26112265 PMCid:PMC4481042

Ngcamu, B.S. \& M.A.H. Wallis 2011. Disaster Response and Recovery in Two Informal Settlements: A Local Government Perspective. Corporate Ownership \& Control 8,3.

https://doi.org/10.22495/cocv8i3c6p4

Ngcamu, B.S. 2011. Disaster Risk Management in Local Government: A Case Study of Foreman and Kennedy Road Informal Settlements, eThekwini Municipality. Ph.D. thesis, Durban University of Technology.

https://doi.org/10.22495/cocv8i3c3p1

NICD 2020. COVID-19 Update 1. https://www.nicd.ac.za/covid-19-update-1/ Nyadera, I.N. \& F. Onditi 2020. COVID-19 Experience among Slum Dwellers in Nairobi: A Double Tragedy or Useful Lesson for Public Health Reforms? International Social Work.

https://doi.org/10.1177/0020872820944997

Nyashanu, M., P. Simbanegavi \& I. Gibson 2020. Exploring the Impact of COVID-19 Pandemic Lockdown on Informal Settlements in Tshwane Gauteng Province, South Africa. Global Public Health 1-11.

https://doi.org/10.1080/17441692.2020.1805787

PMid:32780633

Pillay, K. 2019a. EThekwini Disaster Management Unit 'Compromising City' The Mercury March 20. Available at: 
https://www.iol.co.za/mercury/news/ethekwini-disaster-managementunit-compromising-city-19986131

(Accessed on 12 March 2020).

Pillay, K. 2019b. City Disaster Unit 'Short Staffed and Ill Prepared'. The Mercury July 18.

RSA 1996. Constitution of the Republic of South Africa. Pretoria: Government Printers.

RSA 2000. Local Government Municipal Systems Act, Act No 32 of 2000. Pretoria: Local Government Printers.

RSA 2002. Disaster Management Act (Act No.2002). Pretoria: Government Printers.

RSA 2015. South African Disaster Management Amendment Act No. 16 of 2015. Pretoria: Government Printers.

RSA 2020. Department of Co-Operative Governance and Traditional Affairs

Declaration of a National State of Disaster, March 15. Available at:

https://www.gov.za/sites/default/files/gcis document/202003/43096gon

313.pdf (Accessed on 09 May 2020)

Shah, A. 2017. Ethnography? Participant Observation, a Potentially Revolutionary Praxis. HAU: Journal of Ethnographic Theory 7,1: 45 - 59. https://doi.org/10.14318/hau7.1.008

Singh, O. 2020. 44 Dead, Hundreds Injured and at Least 30000 Affected by

KZN Summer Storms. TimesLive, January 9. Available at:

https://www.timeslive.co.za/news/south-africa/2020-01-09-44-dead-

hundreds-injured-and-at-least-30000-affected-by-kzn-summer-storms/

(Accessed on 06 April 2020.)

Statistics SA. 2020. http://www.statssa.gov.za/

(Accessed on 30 April 2020.)

Stiegler, N. \& J.P. Bouchard May 2020. South Africa: Challenges and Successes of the COVID-19 Lockdown. Annales Médico-psychologiques revue psychiatrique. Elsevier Masson.

https://doi.org/10.1016/j.amp.2020.05.006

PMid:32836300 PMCid:PMC7250766

The World Bank. GINI index (World Bank estimate). 2014 (Accessed on 30 April 2020.) https://data.worldbank.org/indicator/SI.POV.

The World Bank 2020 South African Overview. Available at:

https://www.worldbank.org/en/country/southafrica/overview

(Accessed May 20 2020) 
United Nations. General Assembly. (1949). Universal Declaration of Human Rights (3381). Department of State, United States of America.

Van Belle, S., C. Affun-Adegbulu, W. Soors, P.N. Srinivas, G. Hegel, W. van Damme, D. Saluja, I. Abejirinde, E. Wouters, C. Masquillier \& H. Tabana 2020. COVID-19 and Informal Settlements: An Urgent Call to Rethink Urban Governance. International Journal for Equity in Health 19,1:1 - 2. https://doi.org/10.1186/s12939-020-01198-0

PMid:32493415 PMCid:PMC7267749

Wilkinson, A. 2020. Local Response in Health Emergencies: Key Considerations for Addressing the COVID-19 Pandemic in Informal Urban Settlements. Environment and Urbanization. p.0956247820922843.

Zukiswa Pikoli 6 April 2020. Demolitions and Evictions: The eThekwini Council has Gone 'Rogue'. Daily Maverick 06 April.

Evangelos A. Mantzaris Retired Research Professor Mangosuthu University of Technology Mantzaris.Evangelos@mut.ac.za

Bethuel Sibongiseni Ngcamu Head of Department: Public Management and Leadership Nelson Mandela University bethuel.ngcamuza@mandela.ac.za 